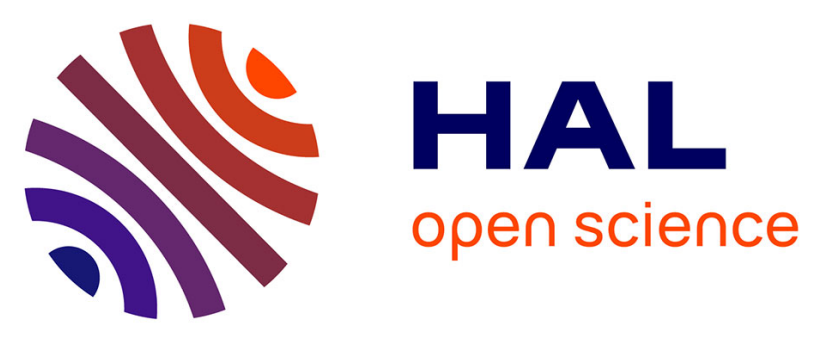

\title{
Nauclea latifolia Smith (Rubiaceae) exerts antinociceptive effects in neuropathic pain induced by chronic constriction injury of the sciatic nerve.
}

Germain Sotoing Taïwe, Elisabeth Ngo Bum, Emmanuel Talla, Théophile Dimo, Amadou Dawe, Valérie Sinniger, Bruno Bonaz, Ahcène Boumendjel, Michel de Waard

\section{To cite this version:}

Germain Sotoing Taïwe, Elisabeth Ngo Bum, Emmanuel Talla, Théophile Dimo, Amadou Dawe, et al. Nauclea latifolia Smith (Rubiaceae) exerts antinociceptive effects in neuropathic pain induced by chronic constriction injury of the sciatic nerve.. Journal of Ethnopharmacology, 2014, 151 (1), pp.445-51. 10.1016/j.jep.2013.10.068 . inserm-00908988

\section{HAL Id: inserm-00908988 https://www.hal.inserm.fr/inserm-00908988}

Submitted on 25 Nov 2013

HAL is a multi-disciplinary open access archive for the deposit and dissemination of scientific research documents, whether they are published or not. The documents may come from teaching and research institutions in France or abroad, or from public or private research centers.
L'archive ouverte pluridisciplinaire HAL, est destinée au dépôt et à la diffusion de documents scientifiques de niveau recherche, publiés ou non, émanant des établissements d'enseignement et de recherche français ou étrangers, des laboratoires publics ou privés. 


\section{Graphical abstract}

Nauclea latifolia Smith (Rubiaceae) exerts antinociceptive effects in neuropathic pain induced by chronic constriction injury of the sciatic nerve

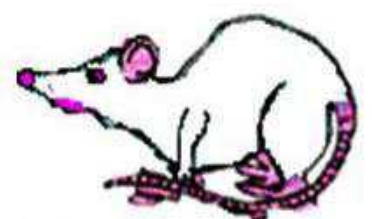

Induction of neuropathic pain in rat

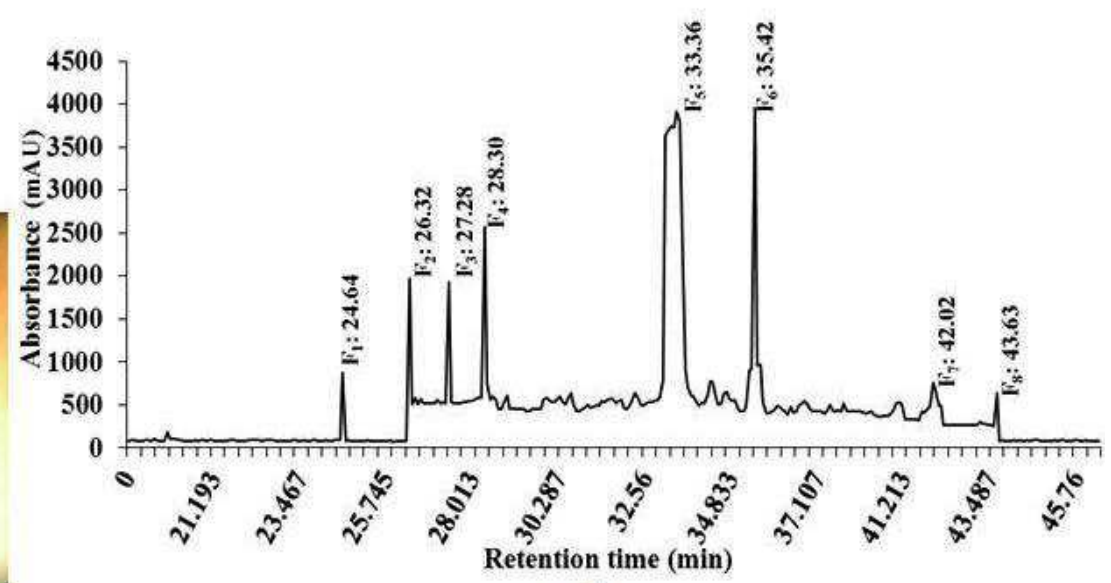

Study of antiallodynic and anti-hyperalgesic effects of alkaloids fraction from Nauclea latifolia 
Nauclea latifolia Smith (Rubiaceae) exerts antinociceptive effects in neuropathic pain induced by chronic constriction injury of the sciatic nerve

Germain Sotoing Taïwe $\mathrm{e}^{\mathrm{a}, \mathrm{b}, \mathrm{c}, *}$, Elisabeth Ngo Bum ${ }^{\mathrm{d}}$, Emmanuel Talla ${ }^{\mathrm{e}}$, Théophile Dimo Amadou Dawe $e^{\mathrm{g}}$, Valérie Sinniger ${ }^{\mathrm{b}, \mathrm{c}}$, Bruno Bonaz ${ }^{\mathrm{b}, \mathrm{c}}$, Ahcène Boumendjel ${ }^{\mathrm{c}, \mathrm{h}, \mathrm{i}}$ and Michel De Waard ${ }^{\text {b,c,i }}$

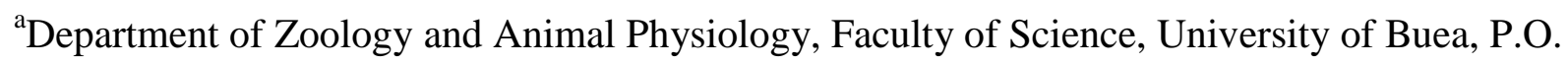
Box 63 Buea, Cameroon.

${ }^{\mathrm{b}}$ Unité Inserm U836, Grenoble Institute of Neuroscience, Chemin Fortuné Ferrini, Site santé de la Tronche, P.O. Box 170, 38042 Cedex 9, Grenoble France.

${ }^{\mathrm{c}}$ Université Joseph Fourier, Grenoble, France.

${ }^{\mathrm{d} D e p a r t m e n t ~ o f ~ B i o l o g i c a l ~ S c i e n c e s, ~ F a c u l t y ~ o f ~ S c i e n c e, ~ U n i v e r s i t y ~ o f ~ N g a o u n d e ́ r e ́, ~ P . O . ~ B o x ~}$ 454 Ngaoundere, Cameroon.

${ }^{\mathrm{e}}$ Department of Chemistry, Faculty of Science, University of Ngaoundéré, P.O. Box 454 Ngaoundere, Cameroon.

${ }^{\mathrm{f}}$ Department of Animal Biology and Physiology, Faculty of Science, University of Yaoundé I, P.O. Box 812 Yaoundé, Cameroon.

${ }^{\mathrm{g}}$ Department of Chemistry, Higher Teachers' Training College, University of Maroua, P. O. Box 55, Maroua, Cameroon.

${ }^{\mathrm{h}}$ Unité CNRS 5063, Department of Medicinal Chemistry, P.O. Box 53, 38041 Grenoble Cedex 9, France.

${ }^{\mathrm{i}}$ Smartox Biotechnologies, Floralis, Biopolis, 5 Avenue du Grand Sablon, 38700 La Tronche, France. 
*Corresponding author. Tel.: 00237777186 70; Fax: 00237221573 70; E-mail address: taiwe_sotoing@yahoo.fr (G.S. Taïwe), Department of Zoology and Animal Physiology, Faculty of Science, University of Buea, P.O. Box 63, Buea, Cameroon.

\section{Abstract}

Ethnopharmacological relevance: The roots of Nauclea latifolia Smith (Rubiaceae) popularly known as "koumkouma" is used in traditional Cameroonian medicine as neuropathic pain remedy and for the treatment of headache, inflammatory pain and convulsion.

Aim of the study: This study was conducted to evaluate the antinociceptive effects of the alkaloid fraction isolated from Nauclea latifolia in neuropathic pain induced by chronic constriction injury (CCI) of the sciatic nerve in rat.

Materials and methods: Bioactive-guided fractionation of the root extracts of Nauclea latifolia using the Von Frey in a rat model of neuropathic pain (Benett model), afforded a potent antihyperalgesic fraction IV. Further fractionation of this fraction was performed by highperformance liquid chromatography (HPLC), yielded eight sub-fractions $\left(\mathrm{F}_{1}-\mathrm{F}_{8}\right)$ which were tested for antinociceptive effects. The alkaloid fraction $\left(\mathrm{F}_{3}\right)$ collected by HPLC, exhibited potent antinociceptive effects, and the anti-allodynic and anti-hyperalgesic effects of this fraction $(8,16,40$ and $80 \mathrm{mg} / \mathrm{kg}$ ) were determined using the von Frey and acetone tests respectively in a rat model of neuropathic pain. Rota-rod performance and catalepsy tests were used for the assessment of motor coordination.

Results: The alkaloid fraction $(80 \mathrm{mg} / \mathrm{kg}$ ) administered intraperitoneally induced a completely decreased hyperalgesia 90 min post-dosing. In the acetone test, the Nauclea latifolia fraction at $80 \mathrm{mg} / \mathrm{kg}$ showed its maximal anti-allodynic effects $120 \mathrm{~min}$ post-injection. The areas under the curve (AUC) of the anti-allodynic or anti-hyperalgesic effects produced by the alkaloid fraction at $80 \mathrm{mg} / \mathrm{kg}$ were significantly $(\mathrm{p}<0.001)$ greater than the AUC of effects 
produced by vehicle in CCI rats. The alkaloid fraction did not exhibit any significant effects on the spontaneous locomotor activity of the mice in rota-rod performance and no sign of catalepsy was observed.

Conclusion: The analysis of the effects, expressed as the time course of AUC, supports the traditional use of Nauclea latifolia in neuropathic pain therapy. The pharmacological and chemical studies are continuing in order to characterize the mechanism(s) responsible for this anti-hyperalgesic and anti-allodynic action and also to identify the active substances present in the roots extracts of Nauclea latifolia.

Keywords: Nauclea latifolia, neuropthic pain, anti-hyperalgesic, anti-allodynic, traditional medicine.

\begin{abstract}
Abbreviations
ANOVA, analysis of variance; ATCC, American Type Culture collection; AUC, areas under the curve; $\mathrm{CCI}$, chronic constriction injury; $\mathrm{CHO}$, chinese hamster ovary; $\mathrm{EC}_{50}$, the $50 \%$ effective concentration; $\mathrm{F}_{1}$, fractions; HPLC, high-performance liquid chromatography; $\mathrm{LD}_{50}$, median lethal dose; L-NAME, $\mathrm{N}_{\omega}$-L-nitro-arginine methyl ester; MTT; 3-(4, 5 dimethylthiazol-2-yl)-2, 5-diphenyl-tetrazolium bromide; NIH, National Institutes of Health.
\end{abstract}

\title{
1. Introduction
}

The pathophysiological mechanisms underlying neuropathic pain have been reviewed extensively in recent years, and the results reflect both peripheral and central sensitization mechanisms (Moalem and Tracey, 2006). The International Association for the Study of Pain defines neuropathic pain as pain initiated or caused by a primary lesion or dysfunction in the nervous system (Merskey, 1991). Clinically, the presence of neuropathic pain is often 
characterized by stimulus-independent persistent pain or abnormal sensory perception of pain, such as allodynia (a painful response to a normally innocuous stimulus) and hyperalgesia (exaggerated pain sensations as a result of exposure to a mildly noxious stimulus) (Ueda and Rashid, 2003). Neuropathic pain is pain that arises from damage to the part of the nervous system that carries sensory information to the brain. It is difficult to treat because of its severity, duration and resistance to simple painkillers.

Examples of central neuropathic pain include post-stroke pain, affecting up to $8 \%$ of post-stroke patients, and neuropathic pain associated with multiple sclerosis in $50 \%$ of patients and with spinal cord injury in $40 \%$ of patients (Werhagen et al., 2007). Peripheral neuropathic pain states include painful diabetic neuropathy affecting approximately $25 \%$ of people with diabetes, sciatica, post-surgical and post-traumatic neuralgias. Post herpetic neuralgia is an example of a mixed neuropathic pain, with both peripheral and central mechanisms, affecting a significant proportion of patients following shingles (Andersen et al., 1995; Davies et al., 2006; Hewitt et al., 1997; Jung et al., 2004; Kehlet et al., 2006; Osterberg et al., 2005; Siddall et al., 2003). Most patients with neuropathic pain respond poorly to traditional analgesics and many require a multidisciplinary approach. With current available treatments, only $30-50 \%$ of patients with neuropathic pain experience meaningful improvement in pain and function, and a long-term commitment from the patient and physician are required to ensure compliance and appropriate outcomes (Bennett, 2007).

In the north of Cameroon, the leaves of Nauclea latifolia Smith (Rubiaceae) is used in traditional medicine for the treatment of cerebral malaria, behavioural disturbances in mentally-retarded children or central nervous system diseases, such as anxiety, depression and epilepsy (Dalziel, 1937; Adjanohoun et al., 1996; Arbonnier, 2000). The roots decoction of Nauclea latifolia is effective in cases of fever, headache, migraine, pain, inflammatory disorders and neuropathic pain (Biholong, 1986; Adjanohoun et al., 1996; Arbonnier, 2000; 
Amos et al., 2005). Interested in investigating the pharmacological properties of Nauclea latifolia Abbah et al. (2009) and Taïwe et al. (2011) have demonstrated that oral administration of Nauclea latifolia extracts cause antipyretic, antinociceptive and antiinflammatory effects. Earlier chemical studies of Nauclea latifolia have indicated the presence of Naucleamides A-F, a new monoterpene indole alkaloids, strictosamide (Shigemori et al., 2002, Ata et al., 2009), flavonoids, saponins, tannins, anthraquinones and phenols in the Nauclea latifolia extracts (Ngo Bum et al., 2009; Taïwe et al., 2011).

In the present study, in order to provide a pharmacological basis to the traditional use of Nauclea latifolia as antinociceptive therapy in neuropathic pain and to discover novel analgesic drugs from natural resources, we investigated the antiallodynic and antihyperalgesic effects of the alkaloid fraction from Nauclea latifolia roots on CCI of the sciatic nerve, a rat model of neuropathic pain, using the Von Frey and acetone tests.

\section{Materials and methods}

\subsection{Plant material}

The roots of Nauclea latifolia was harvested in March 2009 from the National Park of Benoué (North Cameroon) and identified in the National Herbarium, Yaoundé Cameroon by comparison to an existing voucher specimen No. 20144/SRF/Cam.

\subsection{Solvent-guided fractionation of Nauclea latifolia and bioactivity guided studies}

The dried and powdered roots of Nauclea latifolia (1000 g) were extracted with acetone/ $\mathrm{H}_{2} \mathrm{O}(7: 3 ; 51)$ at room temperature. The combined extracts were evaporated in vacuo to afford a dark residue (381.61 g). The residue was suspended in warm water $\left(\begin{array}{ll}1 & 1\end{array}\right)$ and then extracted successively with ethyl acetate $(0.51 \times 3)$ and n-butanol $(0.51 \times 3)$, and concentrated to give residue A (133.25 g) and B (371.14 g), respectively. The latter was 
resolved in warm water $(11)$, acidified with $\mathrm{HCl}(1 \mathrm{~N})$ to $\mathrm{pH} 4-5$, and extracted with $\mathrm{CHCl}_{3}$ $(0.51 \times 3)$. The aqueous layer was neutralized with $\mathrm{NaOH}(1 \mathrm{~N})$ to $\mathrm{pH} 9-10$ and extracted with $\mathrm{CHCl}_{3}(0.51 \times 3)$ once again and concentrated in vacuo to obtain the crude base $(136.12$ $\mathrm{g} ; 36.67 \%)$. The crude base (136.12 g) was subjected to a chromatography column with silica gel and eluted with $\mathrm{CHCl}_{3} / \mathrm{CH}_{3} \mathrm{OH} / 28 \% \mathrm{NH}_{4} \mathrm{OH}(50: 1: 0.1 \rightarrow 3: 1: 0.1)$ to afford thirteen fractions: Fr. I (12.51 g; 9.19\%), Fr. II (6.34 g; 4.66\%), Fr. III (17.68 g; 12.99\%), Fr. IV (16.35 g; 12.01\%), Fr. V (11.45 g; 8.41\%), Fr. VI (92.42 mg; 0.07\%), Fr. VII (75.43 mg; 0.05\%), Fr. VIII (41.27 mg; 0.03\%), Fr. IX (39.15 mg; 0.03\%), Fr. X (4.21 g; 3.09\%), Fr. XI (1.29 g; 0.95\%), Fr. XII (56.94 mg; 0.04\%), Fr. XII (513.54 mg; 0.38\%). Bioactivity-guided studies on the extract and fractions using Von Frey test showed that the fraction IV from the roots of Nauclea latifolia significantly attenuated mechano-hyperalgesia of all CCI rats with $85.26 \pm 9.17 \%$, compared to the control group.

\subsection{Sample preparation, chromatographic analysis and bioactivity guided studies}

$10 \mathrm{mg}$ sample of the fractions IV was dissolved in $10 \mathrm{ml}$ methanol. The solution was filtered through membrane filter (pore size $0.45 \mu \mathrm{m}$ ) prior to high-performance liquid chromatography analysis. The sample was analysed by means of a HPLC system (AKTA ${ }^{\mathrm{TM}}$ Purifier, Amersham Biosciences). The alkaloid fraction derived from Nauclea latifolia was analysed by HPLC using a Vydac C18 column $(218 \mathrm{TP} 1010,25 \times 10 \mathrm{~cm}, 10 \mu \mathrm{m})$, and for elution of the constituents, a gradient of two solvents denoted A and B was employed. The mobile phases were (A) $90 \%$ acetonitrile with water and (B) $0.1 \%$ trifluoroacetic acid with water. The flow rate used was $1.0 \mathrm{ml} / \mathrm{min}$ and the injection volume was $10 \mathrm{ml}$. The retention time and UV spectrum of major peaks were analyzed. The eluant was monitored at $215 \mathrm{~nm}$. The fractions eluted were combined, and then lyophilized $\left[\mathrm{F}_{1}(0.03 \mathrm{mg} ; 0.30 \%), \mathrm{F}_{2}(0.1 \mathrm{mg}\right.$; $10 \%), \mathrm{F}_{3}(0.13 \mathrm{mg} ; 1.30 \%) ; \mathrm{F}_{4}(0.07 \mathrm{mg} ; 0,70 \%), \mathrm{F}_{5}(0.11 \mathrm{mg} ; 1.10 \%), \mathrm{F}_{6}(0.04 \mathrm{mg} ; 0.40 \%)$, 
$\left.\mathrm{F}_{7}(0.08 \mathrm{mg} ; 0.80 \%), \mathrm{F}_{8}(0.16 \mathrm{mg} ; 1.60 \%)\right]$ (Figure 1$)$, to afford the products as powders. Further activity-guided studies on the sub-fractions $\left(\mathrm{F}_{1}-\mathrm{F}_{8}\right)$ showed that the powders yielded by $F_{3}$ exhibited the most potent antinociceptive effects by causing a dose-dependent inhibition of mechanical hyperalgesia in CCI rats using Von Frey test. The collected fraction $\mathrm{F}_{3}$ was dissolved in vehicle (saline containing dimethyl sulfoxyde 2\%) and screned for further activities.

\section{4. Animals}

Male Wistar rats (160-180 g), and male and female Swiss mice (25-30 g) were used. All animals were housed under standardized conditions in the animal facility on a $12 \mathrm{hrs}$ light/dark cycle with food and water available ad libitum. The investigation conforms to the Guide for the Care and Use of Laboratory Animal published by the US National Institutes of Health (NIH; publication No. 85-23, revised 1996) and received approval of the local ethical committee for animal handling and experimental procedure (Ref n॰ FW-IRB00001954).

\subsection{Production of neuropathy and behavioral testing}

\subsubsection{Surgery}

The chronic constriction injury of the sciatic nerve model was employed according to methods described by Bennett and Xie (Bennett and Xie, 1988). Under thiopental sodium anesthesia (Sigma chemical, St Louis, USA, $35 \mathrm{mg} / \mathrm{kg}$; i.p.), the right common sciatic nerve was exposed by blunt dissection through the biceps femoris, at the level of mid-thigh. Proximal to the sciatic trifurcation, the nerve was freed of adhering tissue, and four ligatures with 3-0 silk thread were tied loosely around the nerve with a spacing of about $1 \mathrm{~mm}$, taking care not to interrupt the epineural circulation. After surgery, the muscle and skin were closed in two layers using absorbable chronic catgut 4-0 for the muscle and 3-0 silk thread for the 
skin. In sham-operated controls, an identical surgical procedure was performed, except that the sciatic nerve was not ligatured. All surgical procedures were performed under normal sterile conditions by the same person. After operation, the rats were allowed to recover for 1 week.

\subsubsection{Von Frey test}

To quantify mechanical sensitivity of the foot, a brisk foot withdrawal in response to normally innocuous mechanical stimuli was measured as described previously (Kim and Chung 1992). Six rats were used for each treatment ( $n=6$ per group). The rats were placed in acrylic cages on top of a wire mesh grid that allowed their paws access to the Von Frey filaments. The rats were adapted to the testing situation, and they were allowed to habituate until exploratory behaviour diminished for at least $10 \mathrm{~min}$ before stimulation was initiated. Bending forces of $1,6,10$ and $15 \mathrm{~g}$ to the mid-plantar skin of each hind paw were then applied in increasing order from the weakest to the strongest. Beginning with the lowest force, the filament was placed on the skin until it bowed slightly, with each filament presented ten times at a rate of about 1/s. The paw-withdrawal threshold was defined as the percent force eliciting an active withdrawal on the affected ipsilateral paw. A response was recorded every $30 \mathrm{~min}$ for $180 \mathrm{~min}$ post-dosing if the rat withdrew its hind paw from the filament. The effects of acute administration of the alkaloid fraction from Nauclea latifolia (8, 16, 40 and 80 $\mathrm{mg} / \mathrm{kg}$; i.p.), morphine (Sigma chemical, St Louis, USA, $5.6 \mathrm{mg} / \mathrm{kg} ;$ s.c.) or vehicle (10 $\mathrm{ml} / \mathrm{kg}$; saline containing dimethyl sulfoxyde $2 \%$, i.p.) on mechanical sensitivity were tested between at day 12 post-surgery.

\subsubsection{Acetone test}


To quantify cold sensitivity of the foot, brisk foot withdrawal in response to acetone application was measured as described previously (Choi et al., 1994). Six rats were used for each treatment ( $\mathrm{n}=6$ per group). With the animals inside acrylic cages on the elevated grid, a drop of acetone was delicately applied to the plantar surface of the hind paw without touching the skin using a blunt plastic needle connected to a syringe. A response was recorded if the rat withdrew its hind paw in response to acetone application. The time spent with the leg withdrawn from the floor during the $60 \mathrm{~s}$ following exposure to acetone was recorded. Both hind legs were tested in each animal, beginning with the unoperated left leg, and each stimulus was applied three times at intervals of approximately 5 min. The duration of lifting of the hind paw after acetone stimuli was recorded with a stopwatch every $30 \mathrm{~min}$ for $180 \mathrm{~min}$ post-dosing (Dowdall et al., 2005). The effects of acute administration of the alkaloid fraction from Nauclea latifolia $(8,16,40$ and $80 \mathrm{mg} / \mathrm{kg}$; i.p.), morphine (5.6 mg/kg; s.c.) or vehicle (10 ml/kg; saline containing dimethyl sulfoxyde $2 \%$, i.p.; adequate controls were performed with the corresponding vehicles in CCI and sham rats) on cold sensitivity were tested between day 12 and day 14 post-surgery.

\subsection{Motor assessment and signs of catalepsy}

The motor coordination test was performed to determine side effects of the Nauclea latifolia alkaloid fraction using the rotating rod method (Taïwe et al., 2011). The bar rotated at a constant speed of 16 revolutions per min. A preliminary selection of mice was made on the day of experiment prior to administration of extract or morphine $\left(t_{0} b\right)$, excluding those that did not remain on the rota-rod bar for two consecutive periods for $45 \mathrm{sec}$ each. Six mice were used for each treatment ( $n=6$ per group). The integrity of motor coordination was assessed on the basis of the number of falls from the rota-rod in $180 \mathrm{sec}$. Selected animals were tested immediately at $0\left(\mathrm{t}_{0} \mathrm{a}\right), 30,60,90$, and $120 \mathrm{~min}$ after administrations of the alkaloid fraction 
from Nauclea latifolia (8, 16, 40 and $80 \mathrm{mg} / \mathrm{kg}$, i.p.), morphine $(5.6 \mathrm{mg} / \mathrm{kg}$, s.c.), or vehicle (10 ml/kg; saline containing dimethyl sulfoxyde $2 \%$, i.p.).

Catalepsy was evaluated according to the standard bar hanging procedure by placing the naive mice with both forelegs over a horizontal bar, elevated $4.5 \mathrm{~cm}$ from the floor (Sanberg et al., 1988). Catalepsy was considered finished when the forepaw touched the floor or when the mouse climbed the bar. Eight mice were used for each treatment $(n=8$ per group). Measurement was performed 30 and 60 min after administration of the alkaloid fraction from Nauclea latifolia (8, 16, 40 and $80 \mathrm{mg} / \mathrm{kg}$; i.p.), morphine (5.6 mg/kg; s.c.) or vehicle $(10 \mathrm{ml} / \mathrm{kg}$; saline containing dimethyl sulfoxyde $2 \%$, i.p.; adequate controls were performed with the corresponding vehicles in CCI and sham rats). The time during which the mouse maintained the cataleptic position was recorded for up to $300 \mathrm{sec}$, with three attempts allowed to replace the animal over the glass bar.

\subsection{Acute toxicity and cell viability essay}

The acute toxicity test for the alkaloid fraction from Nauclea latifolia was carried out to evaluate any possible toxicity. Mice of either sex ( 5 per sex $=10$ per group) were divided into control and test groups. The first group served as a normal control treated with vehicle (10 ml/kg; saline containing dimethyl sulfoxyde $2 \%$, i.p.). The alkaloid fraction from Nauclea latifolia was administered intraperitonealy to different groups at the increasing doses of 160, $320,640,960,1280,1600 \mathrm{mg} / \mathrm{kg}$. After injections of the alkaloid fraction from Nauclea latifolia, mice were allowed access to food and water ad libitum and all animals were observed for general behavioral and body weight changes, hazardous symptoms and mortality for a period of 14 days after treatment (Taïwe et al., 2011). The median lethal dose $\left(\mathrm{LD}_{50}\right)$ was estimated according to the method described by Litchfield and Wilcoxon (1949). 
Confirmatory tests were carried out and the $\mathrm{LD}_{50}$ was calculated from the graph of probit mortality against dose of the extract.

Chinese hamster ovary $(\mathrm{CHO})$ cell line from American Type Culture collection (ATCC) were maintained at $37^{\circ} \mathrm{C}$ in $5 \% \mathrm{CO} 2$ in $\mathrm{F}-12 \mathrm{~K}$ nutrient medium (InVitrogen) supplemented with 10\% (v/v) heat-inactivated fetal bovine serum (InVitrogen) and 10,000 units/ml streptomycine and penicillin (InVitrogen). Chinese cell ovary cell were seeded into 96 well micro plates at density of approximately $8 \times 10^{8}$ cells/well. After 2 days of culture, the cells were incubated for 24 hours at $37^{\circ} \mathrm{C}$ with various concentrations of the alkaloid fraction from Nauclea latifolia (0, 20, 40, 80, 160, 320, 640, 960, 1280 and $1600 \mu \mathrm{g} / \mathrm{ml})$. Control wells containing cell culture medium alone or with cells, both without Nauclea latifolia fraction addition, were included in each experiment. The cells were then incubated 3(4, 5-dimethylthiazol-2-yl)-2, 5-diphenyl-tetrazolium bromide (MTT; Sigma, St Louis, MO, USA) for $30 \mathrm{~min}$. Conversion of MTT into purple colored MTT formazan by the living cells indicated the extent of cell viability. The crystals were dissolved with dimethyl sulfoxide and the optical density was measured at $540 \mathrm{~nm}$ using microplate reader (Biotek ELx-800, Mandel Scientific Inc.) for quantification of cell viability. All assays were run in triplicates. Results were plotted as percent of cytotoxicity and concentration-response curves were fitted using Graph Pad Prism in order to determine the $50 \%$ effective concentration $\left(\mathrm{EC}_{50}\right)$ (Poillot et al., 2010).

\subsection{Data analyses and statistics}

Data are expressed as mean \pm S.E.M. The cumulative anti-nociceptive effect during the entire observation period (180 min) was determined as the area under the curve (AUC) of the time course. The AUCs for each of the assayed drugs were calculated by the trapezoidal method (Rowland and Tozer, 1989). The data were compared using a two-way analysis of 
variance (ANOVA) followed by Bonferroni's post-hoc tests. A significant statistical difference was determined by value of at least $\mathrm{p}<0.05 . \mathrm{ED}_{50}$ values and $95 \%$ confidence intervals $(95 \% \mathrm{CI})$ were determined at the time of the peak effect for each drug by semilogarithmic regression analysis or according to Litchfield and Wilcoxon (1949).

\section{Results}

\subsection{Effects of the alkaloid fraction from Nauclea latifolia on mechanical hyperalgesia}

Ten days after surgery, CCI rats developed statistically significant increases in responses to $1,6,10$ and $15 \mathrm{~g}$ von Frey filament stimulation. CCI rats showed $7.25 \pm 1.14 \%$ and $17.29 \pm 3.18 \%$ of response frequency to $1 \mathrm{~g}$ and $6 \mathrm{~g}$ von Frey filament stimuli, respectively, compared with the sham-operated group, which did not show any reaction. Thus, this effect was a mechano-allodynic response. However, the stimuli of $10 \mathrm{~g}$ or $15 \mathrm{~g}$ von Frey filaments produced mechano-hyperalgesic responses in rats on day ten post-surgery. For example, when a $10 \mathrm{~g}$ filament stimuli was used in the sham group, $5.12 \pm 1.53 \%$ was the observed response, while in CCI rats the percentage of response was $65.81 \pm 2.14 \%$. Similarly, the stimuli of $15 \mathrm{~g}$ Von Frey filaments produced mechano-hyperalgesic responses in rats on day twelve post-surgery. When a $15 \mathrm{~g}$ filament stimuli was used in the sham group, $86.87 \pm 2.59 \%$ was the observed antihyperalgesia, while in CCI rats the percentage of response was $8.54 \pm 1.83 \%[\mathrm{~F}(6,38)=92.51 ; \mathrm{p}>0.06] .90 \mathrm{~min}$ post-injection of $80 \mathrm{mg} / \mathrm{kg}$ of the alkaloid fraction from Nauclea latifolia, significantly attenuated mechano-hyperalgesia of all CCI rats with $76.97 \pm 4.21 \%[\mathrm{~F}(6,38)=92.51 ; \mathrm{p}<0.001]$, compared to the vehicule group (Figure 2A). The attenuation was most marked $60 \mathrm{~min}$ after injection for $40 \mathrm{mg} / \mathrm{kg}$, and 180 min for $80 \mathrm{mg} / \mathrm{kg}$. The maximum value of the AUC obtained in the Von test in sham rats (anti-hyperalgesic effects) under these experimental conditions was $288.52 \pm 14.29$ area units (a.u.). At $180 \mathrm{~min}$, the AUC was $198.25 \pm 15.17$ a.u. in CCI animals administered with 80 
$\mathrm{mg} / \mathrm{kg}$ of the alkaloid fraction, indicating that mechano-hyperalgesia had been significantly reversed $[\mathrm{F}(6,38)=92.51 ; \mathrm{p}<0.05]$. The alkaloids fraction showed potent and dose-dependent inhibition of mechanical hyperalgesia with an $\mathrm{ED}_{50}$ value $(95 \% \mathrm{CI})$ of 35.94 (24.25 - 51.39) $\mathrm{mg} / \mathrm{kg}$ (Figure 2B).

\subsection{Effects of alkaloids fraction from Nauclea latifolia on cold allodinia}

The three hour time courses of the anti-allodynic effects of the alkaloid fraction from Nauclea latifolia and morphine after a single i.p. administration are shown as the antiallodynic effects. Pronounced cold allodynia in response to acetone stimulation of the ipsilateral hind paw was observed in the CCI group in the acetone test 12 days after surgery. The alkaloid fraction from Nauclea latifolia at the dose of $80 \mathrm{mg} / \mathrm{kg}$ induced significant antiallodynia effects of all CCI rats with $89.38 \pm 3.59 \%[\mathrm{~F}(6,29)=103.62 ; \mathrm{p}<0.001]$ using the acetone test (Figure 3A). The most pronounced effect was observed 2 hours after administration of the alkaloid fraction at the dose of $80 \mathrm{mg} / \mathrm{kg}$. The percentage baseline allodynia in CCI rats, injected with vehicle, remained the same throughout the observation period, whereas the sham operated group did not present any response to this cold stimulus during the entire $3 \mathrm{hrs}$ period of observation. The maximum value of the AUC obtained in the acetone test (anti-allodynic effect) under these experimental conditions was $271.40 \pm 12.51$ a.u. An AUC of $10.34 \pm 2.59$ a.u. was observed in the CCI rats which did not show antiallodynic effects. The alkaloid fraction showed significant differences at $80 \mathrm{mg} / \mathrm{kg}(149.57 \pm$ 18.54 a.u. $)[\mathrm{F}(6,31)=145.71 ; \mathrm{p}<0.001]$ compared with the CCI control group without treatment. The alkaloid fraction showed efficient anti-allodynic effects in the CCI model, with an $\mathrm{ED}_{50}$ value $(95 \% \mathrm{CI})$ of $38.26(22.31$ - 49.67) $\mathrm{mg} / \mathrm{kg}$ (Figure $3 \mathrm{~B})$.

\subsection{Effects of the alkaloid fraction from Nauclea latifolia on motor coordination}


The effects of the alkaloid fraction from Nauclea latifolia on motor coordination were evaluated by the number of falls from the rotarod apparatus and compared to animals receiving the vehicle. This alkaloid fraction did not affected motor coordination at all doses tested $[\mathrm{F}(5,72)=103.52 ; \mathrm{P}>0.07)$. However, a large effect on motor coordination $(19.44 \pm$ 0.91 falls $)[\mathrm{F}(5,72)=103.52 ; \mathrm{p}<0.001]$ was observed 30 min post administration with morphine at the dose of $5.6 \mathrm{mg} / \mathrm{kg}$, compared with vehicle (Table 1).

The alkaloid fraction from Nauclea latifolia administered intraperitonealy did not induce any cataleptic effect either at low doses or at the higher dose. As can be seen in Figure 4, s.c. administration of morphine $(5.6 \mathrm{mg} / \mathrm{kg})$ induced catalepsy at $30 \mathrm{~min}[\mathrm{~F}(5,32)=$ $124.39 ; \mathrm{p}<0.01]$ and $60 \min [\mathrm{F}(5,32)=124.39 ; \mathrm{p}<0.001]$ (Figure 4).

\subsection{Acute toxicity and cell viability assay}

The results indicated that the acute treatment by intraperitoneal route at doses up to $1600 \mathrm{mg} / \mathrm{kg}$ of the alkaloid fraction from Nauclea latifolia did not produce any sign of toxicity or death in mice during 24 hours of observation. After 14 days, treated mice did not present any visible toxic effect. Furthermore, no lesions or bleedings were observed in internal organs such as lungs, kidneys, liver, heart and stomach. Neither absolute body weight nor body weight gain was affected by Nauclea latifolia fraction administration at all doses throughout the study. Since no death or damage was observed throughout the experiments, the $\mathrm{LD}_{50}$ could not be estimated.

The ability of the alkaloid fraction from Nauclea latifolia to induce cytotoxicity was further investigated by using CHO cells and a standard MTT bioassay (Figure 5). As shown, incubation for $24 \mathrm{hrs}$ of these cells lines with the Nauclea latifolia fraction, up to a concentration of $160 \mu \mathrm{g} / \mathrm{ml}$, produces no cell toxicity. The toxicity values observed were not significantly different from baseline and lower than $9.7 \pm 3.5 \%[F(8,32)=147.25 ; \mathrm{p}>0.07]$. 
However, incubation of $\mathrm{CHO}$ cells with a higher concentration $(640 \mu \mathrm{g} / \mathrm{ml})$ of the Nauclea latifolia fraction produced greater cell death $(30.2 \pm 3.8 \%)[\mathrm{F}(8,32)=147.25 ; \mathrm{p}<0.001]$. The viability of $\mathrm{CHO}$ cells decreased in a concentration-dependent manner (Figure 5) with increasing concentrations of extract $\left(\mathrm{EC}_{50}=772.35 \pm 13.41 \mu \mathrm{g} / \mathrm{kg}\right)$ after $24 \mathrm{~h}$ treatment.

\section{Discussion}

The present study investigated the anti-allodynic and antihyperalgesic effects of the alkaloid fraction from Nauclea latifolia on chronic constriction injury of the sciatic nerve as a model of neuropathic pain. This model is based on a unilateral loose ligation of the sciatic nerve, which is one of the most frequently used models for the study of neuropathic pain and its treatment. Chronic constriction injury in rats simulates the clinical condition of chronic nerve compression such as that occurring in nerve entrapment neuropathy or spinal root irritation by lumbar disk herniation. This model also shows many of the pathophysiological properties of chronic neuropathic pain in human subjects, such as allodynia and hyperalgesia (Bennett and Xie, 1988; De Vry et al., 2004). In this study, 12 days after CCI, the rats showed a relatively high degree of similarity with other studies published on neuropathic pain in terms of the degrees of allodynia and hyperalgesia against cold and mechanical stimuli, demonstrated by the increased responsiveness to acetone stimulus and von Frey filaments (Bennett and Xie, 1988; De Vry et al., 2004; De la O-Arciniega et al., 2009).

The antinociceptive effects of the alkaloid fraction from Nauclea latifolia was well documented herein, as confirmed by the analysis of the AUC of anti-hyperalgesic effects over a time course of 3 hours post-dosing. Also, this alkaloid fraction induced a strong attenuation of cold allodynia, and the anti-allodynic effects persisted for 3 hours post-administration. Similarly, morphine demonstrated antinociceptive effects on mechanical hyperalgesia and cold allodynia at the dose of $5.6 \mathrm{mg} / \mathrm{kg}$. It is the most widely used opioid and the standard 
against which new agents are compared. This opioid drug has demonstrated antinociceptive efficacy in several models of nociception (López-Muñoz et al., 1993), including neuropathic pain (De Vry et al., 2004). Morphine mediates its actions by binding and activating receptors in the peripheral nervous system, as well as those found in inhibitory pain circuits that descend from the midbrain to the spinal cord dorsal horn via presynaptic and, to a lesser extent, postsynaptic $\mu$-opioid receptors modulating nociceptive transmission (Nicholson, 2003). Other studies suggest that Nauclea latifolia extracts remarkably decreased both the acute and delayed phases of formaline-induced pain in animals and also caused a significant reduction in both yeast-induced pyrexia and egg albumin-induced oedema in rats (Abbah et al., 2010; Taïwe et al., 2011). The antinociceptive effects exhibited by Nauclea latifolia extract in the formalin test was reversed by the systemic administration of naloxone (a nonselective opioid receptor antagonist), $\mathrm{N}_{\omega}$-L-nitro-arginine methyl ester (L-NAME, a NO synthase inhibitor) or glibenclamide (an ATP-sensitive $\mathrm{K}^{+}$channel inhibitor) (Taïwe et al., 2011). In the course of pharmacological studies, anticonvulsant, anxiolytic and sedative properties of Nauclea latifolia roots decoction (Ngo Bum et al., 2009; Taïwe et al., 2010) have already been reported from our laboratory. Neuropathic pain and epilepsy share neuronal hyperexcitability as a common underlying mechanism. There are established antiepileptic drugs that target the generation of neuronal hyperexcitability, and some of these have been proven to be effective in the treatment of various forms of neuropathic pain (Sindrup and Jensen, 2000).

The results obtained in our study suggest that inhibition of neuropathic pain by Nauclea latifolia is not related to the reduction of spontaneous locomotor activity of animals and it's not induced catalepsy. The catalepsy test has been used to predict tranquillizer activity as well as to evaluate motor effects of drugs, particularly those related to the extra-pyramidal system (Sanberg, et al., 1988). 
In the present study, we did not observe any mortality case up to the doses of 1600 $\mathrm{mg} / \mathrm{kg}$ of the alkaloid fraction from Nauclea latifolia. Therefore, we may suggest that the extract has no lethal toxicity in mice. As seen, using the more sensitive MTT assay, no cytoxicity has been observed on $\mathrm{CHO}$ cells lines incubated with alkaloids fraction from Nauclea latifolia at $160 \mu \mathrm{g} / \mathrm{ml}$. MTT assay measured the metabolism of 3- $(4,5-$ dimethylthiazol-2-yl)2,5-diphenyl tetrazolium bromide to form formazan precipitate by mitochondrial dehydrogenase which only present in viable cells. Formazan accumulation directly reflected mitochondrial activity, which was an indirect measure of cell viability (Mosmann, 1983).

In summary, a novel antinociceptive action of the alkaloid fraction from Nauclea latifolia has been confirmed against neuropathic pain induced by CCI of the sciatic nerve, a rat model of neuropathic pain, using the Von Frey and acetone tests, and showing no increase in side effects on motor coordination. Moreover, the anti-hyperalgesic and anti-allodynic action demonstrated in the present study supports, at least in part, the ethnomedical uses of this plant.

\section{Acknowledgements}

This research was supported by Grant from the Agence Universitaire de la Francophonie (Bourse Internationale de Formation à la Recherche Doctorale, AUF 2009/2010, Ref.: 1021FR/277/BAC 2009/JGZ/AS) for valuable financial assistance.

\section{References}

Abbah, J., Amos, S., Ngazal, I., Vongtau, H., Adzu, B., Chindo, B., Farida, T., Odutola, A.A., Wammbebe, C., Gamaniel, K.S., 2009. Pharmacological evidence favouring the use of 
Nauclea latifolia in malaria ethnopharmacy: Effect against nociception, inflammation, and pyrexia in rats and mice. Journal of Ethnopharmacology 127, 85-90.

Adjanohoun, J.E., Aboukakar, N., Dramane, K., Ebot, M.E., Ekpere, J.A., Enow-Orock, E.G., Focho, D., Gbile, Z.O., Kamanyi, A., Kamsu, K.J., Keita, A., Mbenkum, T., Mbi, C.N., Mbiele, A.L., Mbome, I.L., Mubiru, N.K., Nancy, W.L., Nkongmeneck, B., Satabu, B., Sofowora, A., Tamze, V., Wirmum, C.K., 1996. Traditional medicine and pharmacopoeia. In: Contribution to Ethnobotanical and Floristic Studies in Cameroon. Centre de Production de Manuels Scolaires, Porto-Novo (Rep. Du Benin), p. 133.

Amos, S., Abbah, J., Chindo, B., Edmond, I., Binda, L., Adzu, B., Buhari, S., Odutola, A.A., Wambebe, C., Gamaniel, K., 2005. Neuropharmacological effects of the aqueous extract of Nauclea latifolia root bark in rats and mice. Journal of Ethnopharmacology 97, 53-57.

Andersen, G., Vestergaard, K., Ingeman-Nielsen, M., Jensen, T.S., 1995. Incidence of central post-stroke pain. Pain 61, 187-193.

Arbonnier, M., 2000. Arbres, arbustes et lianes des zones sèches d'Afrique de l'Ouest Trees, shrubs and lianas of West Africa dry zones, Mali, Ouagadougou: Centre de Coopération Internationale en Recherche Agronomique pour le développement/Muséum national d'histoire naturelle/Union mondiale pour la nature. 1st Edn., (CIRAD/MNHN/UICN).

Ata, A., Udenigwe, C.C., Matochko, W., Holloway, P., Eze, M.O., Uzoegwu, P.N., 2009. Chemical constituents of Nauclea latifolia and their anti-GST and anti-fungal activities. Natural Product Communications 4, 1185-1188.

Bennett, G., Xie, Y.K., 1988. A peripheral mononeuropathy in rat that produces disorders of pain sensation like those seen in man. Pain 33, 87-107.

Bennett, M., 2007. Neuropathic pain. Oxford University Press, Oxford, England. 
Biholong, M., 1986. Contribution à l'étude de la flore du Cameroun: les Astéracées. Thèse de doctorat. Université de Bordeaux III, Bordeaux, France, pp 10 - 50.

Choi, Y., Yoon, Y.W., Na, H.S., Kim, S.H., Chung, J.M., 1994. Behavioral signs of ongoing pain and cold alodynia in a rat model of neuropathic pain. Pain 59, 369-376.

Dalziel, J.M., 1937. The useful plants of West Tropical Africa. Ed. The Crown Agency for the Colonies, London.

Davies, M., Brophy. S., Williams, R., Taylor, A., 2006. The prevalence, severity, and impact of painful diabetic peripheral neuropathy in type 2 diabetes. Diabetes Care 29, 15181522.

De Vry, J., Kuhl, E., Franken-Kunkel, P., Eckel, G., 2004. Pharmacological characterization of the chronic constriction injury model of neuropathic pain. European Journal Pharmacology 491, 137-148.

De la O-Arciniega, M., Díaz-Reval, M.I., Cortés-Arroyo, A.R., Domínguez-Ramírez, A.M., López-Muñoz, F.J., 2009. Anti-nociceptive synergism of morphine and gabapentin in neuropathic pain induced by chronic constriction injury. Pharmacology, Biochemistry and Behavior 92, 457-464.

Dowdall, T., Robinson, I., Meert, F.T., 2005. Comparison of five different rat models of peripheral nerve injury. Pharmacology Biochemistry and Behavior 80, 93-108.

Hewitt, D.J, McDonald, M., Portenoy, R.K., Rosenfeld, B., Passik, S., Breitbart, W., 1997. Pain syndromes and etiologies in ambulatory AIDS patients. Pain 70, 117-123.

Jung, B.F., Johnson, R.W., Griffin, D.R., Dworkin, R.H., 2004. Risk factors for postherpetic neuralgia in patients with herpes zoster. Neurology $62,1545-1555$.

Kehlet, H., Jensen, T.S., Woolf, C.J., 2006. Persistent postsurgical pain: risk factors and prevention. Lancet 367, 1618-25. 
Kim, S.H., Chung, J.M., 1992. An experimental model for peripheral neuropathy produced by segmental spinal nerve ligation in the rat. Pain 50, 355-63.

Litchfield, J.T., Wilcoxon, F., 1949. A simplified method of evaluating dose-effect experiments. Journal of Pharmacology and Experimental Therapeutics 96, 99-113.

López-Muñoz, F.J., Salazar, L.A., Castañeda-Hernández, G., Villarreal, J.E., 1993. A new model to assess analgesic activity: pain-induced functional impairment in the rat (PIFIR). Drug Development Research 28, 169-75.

Merskey, H., 1991. The definition of pain. European Journal of Psychiatry 6, 153-9.

Moalem, G., Tracey, D.J., 2006. Immune and inflammatory mechanisms in neuropathic pain. Brain Research Reviews 51, 240-64.

Mosmann, T., 1983. Rapid colorimetric assay for cellular growth and survival: application to proliferation and cytotoxicity assays. Journal of Immunological Methods 65, 55-63.

Ngo Bum, E., Taïwe, G.S., Moto, F.C.O., Ngoupaye, G.T., Nkantchoua, G.N., Pelanken, M.M., Rakotonirina, S.V., Rakotonirina, A., 2009. Anticonvulsant, anxiolytic and sedative properties of the roots of Nauclea latifolia Smith in mice. Epilepsy and Behavior 15, 434-440.

Nicholson, B., 2003. Responsible prescribing of opioids for the management of chronic pain. Drugs, 63: 17-32.

Osterberg, A., Boivie, J., Thuomas, K.A., 2005. Central pain in multiple sclerosis-prevalence and clinical characteristics. European Journal of Pain 9, 531-42.

Poillot, C., Dridi, K., Bichraoui, H., Pêcher, J., Alphonse, S., Douzi, B., Ronjat, M., Darbon, H., and De Waard, M., 2010. D-maurocalcine, a pharmacologically-inert efficient cell penetrating peptide analogue. The Journal of Biological Chemistry 285, 34168-34180.

Rowland, M., Tozer, N.T., 1989. Clinical pharmacokinetics: concepts and applications. Chapter 19. Lea and Febiger, $2^{\text {nd }}$ edition London. 
Sanberg, P.R., Bunsey, M.D., Giordano, M., Norman, A.B., 1988. The catalepsy test: its ups and downs. Behavioural Neuroscience 102, 748-759.

Shigemori, H., Kagata, T., Ishiyama, H., Morah, F., Ohsaki, A., Kobayash, J., 2002. Nucleamides A-E, new monotherpene indole alkaloids from Nauclea latifolia. Chemical and Pharmaceutical Bulletin, 51, 58-61.

Siddall, P.J., Mc-Clelland, J.M., Rutkowski, S.B., Cousins, M.J., 2003. A longitudinal study of the prevalence and characteristics of pain in the first 5 years following spinal cord injury. Pain, 103: 249-57.

Sindrup, S.H., Jensen, T.S., 2000. Pharmacologic treatment of pain in polyneuropathy. Neurology 55, 915-20.

Taïwe, G.S., Ngo Bum, E., Dimo, T., Talla, E., Weiss, N., Amadou, D., Moto O.F.C., Sidiki, N., Dzeufiet P.D., De Waard M., 2010. Antidepressant, myorelaxant and anti-anxietylike effects of Nauclea latifolia Smith (Rubiaceae) roots extract in murine models. International Journal of Pharmacology 6, 326-333.

Taïwe, G.S., Ngo Bum, E., Dimo, T., Talla, E., Weiss, N., Sidiki, N., Amadou, D., Moto, O.F.C., Dzeufiet, P.D., De Waard, M., 2011. Antipyretic and antinociceptive effects of Nauclea latifolia and possible mechanisms of action. Pharmaceutical Biology 49, 1525.

Ueda, H., Rashid, H., 2003. Molecular mechanism of neuropathic pain. Drug News and Perspectives 16, 605-13.

Werhagen, L., Hultling, C., Molander, C., 2007. The prevalence of neuropathic pain after non traumatic spinal cord lesion. Spinal Cord 45, 609-615.

\section{Figure legends}


Figure 1: HPLC profile of the alkaloid fraction from the roots of Nauclea latifolia alone measured at the wavelength of $215 \mathrm{~nm}$.

Figure 2: Effects of the alkaloid fraction from Nauclea latifolia on mechanical hyperalgesia. Time course of anti-hyperalgesic effects of Nauclea latifolia on mechanical hyperalgesia with a $15 \mathrm{~g}$ von Frey filament after CCI of the sciatic nerve (A). Control groups (sham and CCI) were treated with equivalent volumes of vehicle. Data are expressed as mean $\pm S E M, n=6$, ${ }^{\mathrm{a}} \mathrm{P}<0.05,{ }^{\mathrm{b}} \mathrm{P}<0.01$ and ${ }^{\mathrm{c}} \mathrm{P}<0.001$ versus vehicle $(\mathrm{CCI})$. Dose-response curves expressed as the area under curve (AUC) for the antihyperalgesic effects of Nauclea latifolia with a von Frey filament (15 g) after CCI of the sciatic nerve in rats (B). Rats were treated with vehicle or morphine (Morp; $5.6 \mathrm{mg} / \mathrm{kg}$, s.c.). Bars are means $\pm \mathrm{SEM}, \mathrm{n}=6 . * \mathrm{P}<0.05,{ }^{*} * \mathrm{P}<0.01$ and *** $\mathrm{P}<0.001$ versus vehicle $(\mathrm{CCI})$. Data were analyzed by a two-way analysis of variance (ANOVA) followed by Bonferroni's post-hoc tests.

Figure 3: Effects of the alkaloid fraction from Nauclea latifolia on cold allodinia. Time course of anti-allodynic effects of Nauclea latifolia on cold allodynia after CCI of the sciatic nerve (A). Control groups (sham and CCI) were treated with equivalent volumes of vehicle. Data are expressed as mean \pm SEM, $\mathrm{n}=6,{ }^{\mathrm{a}} \mathrm{P}<0.05,{ }^{\mathrm{b}} \mathrm{P}<0.01$ and ${ }^{\mathrm{c}} \mathrm{P}<0.001$ versus vehicle (CCI). Area under the curve (AUC) of anti-allodynic effects produced by Nauclea latifolia on cold allodynia after CCI of the sciatic nerve (B). Rats were treated with vehicle or morphine (Morp; $5.6 \mathrm{mg} / \mathrm{kg}$, s.c.). Bars are means $\pm \mathrm{SEM}, \mathrm{n}=6$. ${ }^{*} \mathrm{P}<0.05, * * \mathrm{P}<0.01$ and $* * * \mathrm{P}<0.001$ versus vehicle (CCI). Data were analyzed by a two-way analysis of variance (ANOVA) followed by Bonferroni's post-hoc tests. 
Figure 4: Effects of the alkaloid fraction from Nauclea latifolia $(8,16,40$ and $80 \mathrm{mg} / \mathrm{kg}$ ) on catalepsy in mice. Morphine (Morp; $5.6 \mathrm{mg} / \mathrm{kg}$ ) was used as a positive control. Bars are means $\pm \mathrm{SEM}, \mathrm{n}=8 .{ }^{*} \mathrm{p}<0.01$ and $* * * \mathrm{P}<0.001$ compared to vehicle by using a two-way analysis of variance (ANOVA) followed by Bonferroni's post-hoc tests.

Figure 5: Dose response curves for $\mathrm{CHO}$ cell line following 24 hours continuous exposure to the alkaloid fraction from Nauclea latifolia. Results are the mean of three determinations and are expressed as $\%$ cell survival. $\mathrm{EC}_{50}=772.35 \pm 13.41 \mu \mathrm{g} / \mathrm{kg}$.

\section{Tables}


Table 1: Effects of the alkaloid fraction from Nauclea latifolia on motor coordination of mice on the rotarod apparatus.

\begin{tabular}{|c|c|c|c|c|c|c|c|}
\hline \multirow{2}{*}{ Treatments } & \multirow[t]{2}{*}{ Dose (mg/kg) } & \multicolumn{6}{|c|}{ Duration of study (min) } \\
\hline & & $\mathbf{t}_{\mathbf{0}} \mathbf{b}$ & $\mathbf{t}_{\mathbf{0}} \mathbf{a}$ & 30 & 60 & 90 & 120 \\
\hline Vehicle & - & $0.77 \pm 0.11$ & $1.11 \pm 0.39$ & $1.55 \pm 0.83$ & $1.88 \pm 1.02$ & $1.55 \pm 0.48$ & $1.44 \pm 0.49$ \\
\hline N. latifolia & 8 & $0.88 \pm 0.14$ & $1.33 \pm 0.44$ & $1.22 \pm 0.52$ & $1.77 \pm 1.31$ & $1.88 \pm 0.39$ & $1.55 \pm 0.61$ \\
\hline N. latifolia & 16 & $0.77 \pm 0.44$ & $1.22 \pm 0.34$ & $1.11 \pm 0.39$ & $2.16 \pm 1.01$ & $1.66 \pm 0.58$ & $1.66 \pm 0.74$ \\
\hline N. latifolia & 40 & $0.55 \pm 0.44$ & $1.44 \pm 0.59$ & $1.33 \pm 0.81$ & $1.11 \pm 0.61$ & $1.88 \pm 0.59$ & $0.88 \pm 0.19$ \\
\hline N. latifolia & 80 & $0.77 \pm 0.44$ & $1.33 \pm 0.81$ & $1.22 \pm 0.69$ & $1.66 \pm 0.61$ & $2.11 \pm 0.39$ & $1.11 \pm 0.19$ \\
\hline Morphine & 5.6 & $0.66 \pm 0.44$ & $0.88 \pm 0.39$ & $16.55 \pm 1.72 * * *$ & $19.22 \pm 0.91 * * *$ & $19.44 \pm 0.83 * * *$ & $18.77 \pm 0.74 * * *$ \\
\hline
\end{tabular}

Acquisition process of the rotarod performance as expressed by means \pm S.E.M. of number of falls, $\mathrm{n}=6$ animals per group, $* * * \mathrm{p}<0.001$,

significantly different compared to the control. Data were analysed by two-way analysis of variance (ANOVA) followed by Bonferroni's post-

hoc tests. 
Figures

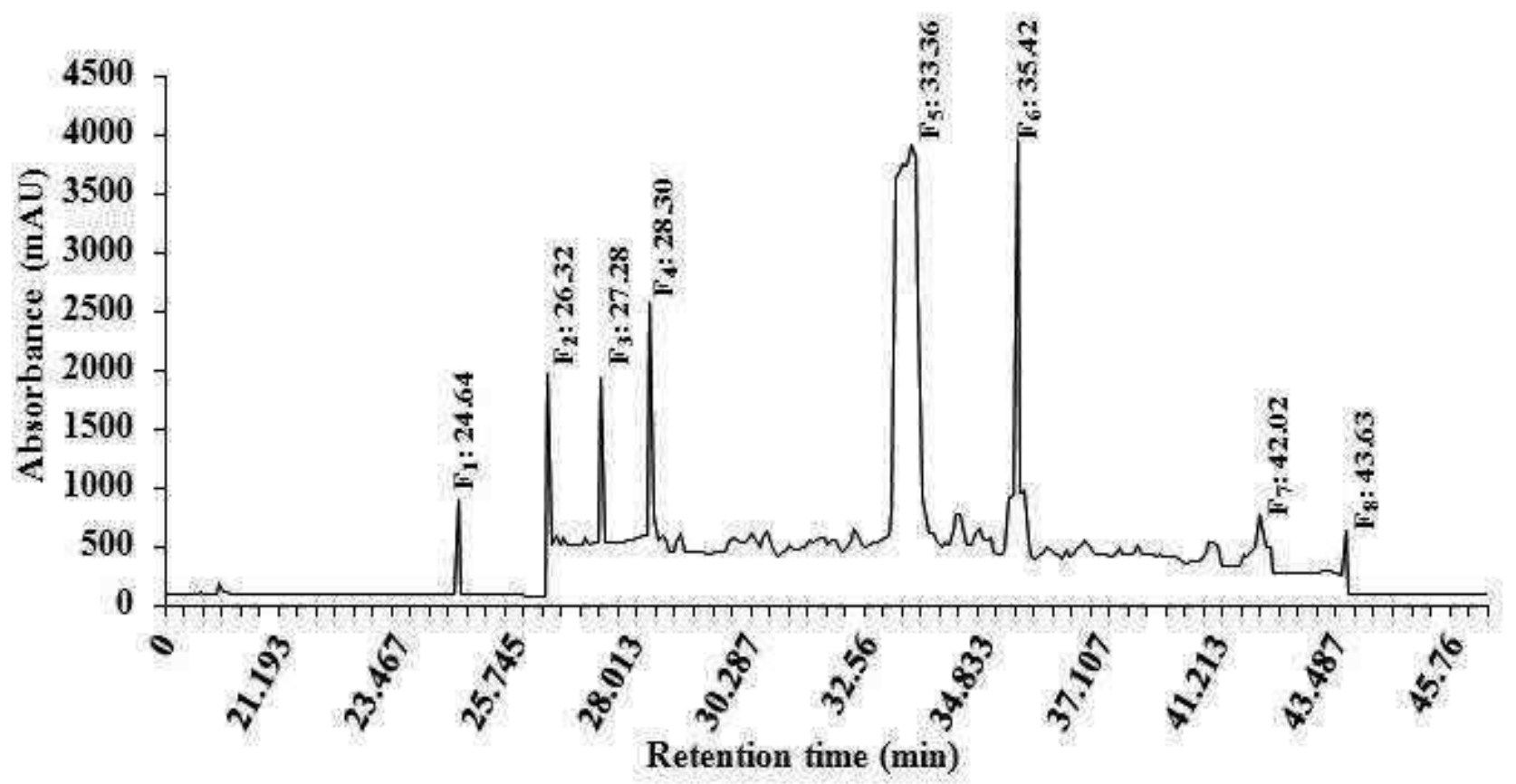

Figure 1: Germain Sotoing Taïwe et al. 

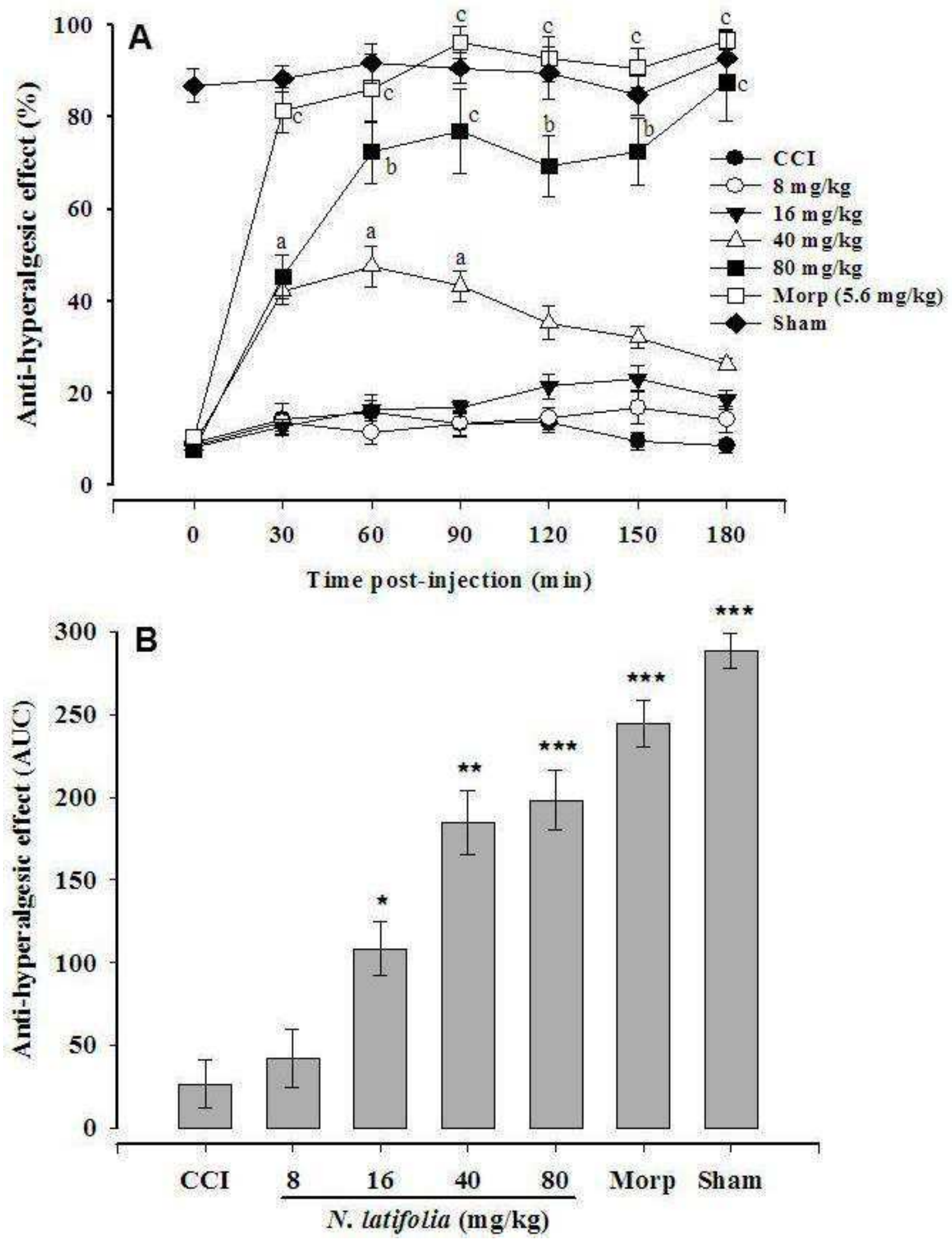

Figure 2: Germain Sotoing Taïwe et al. 


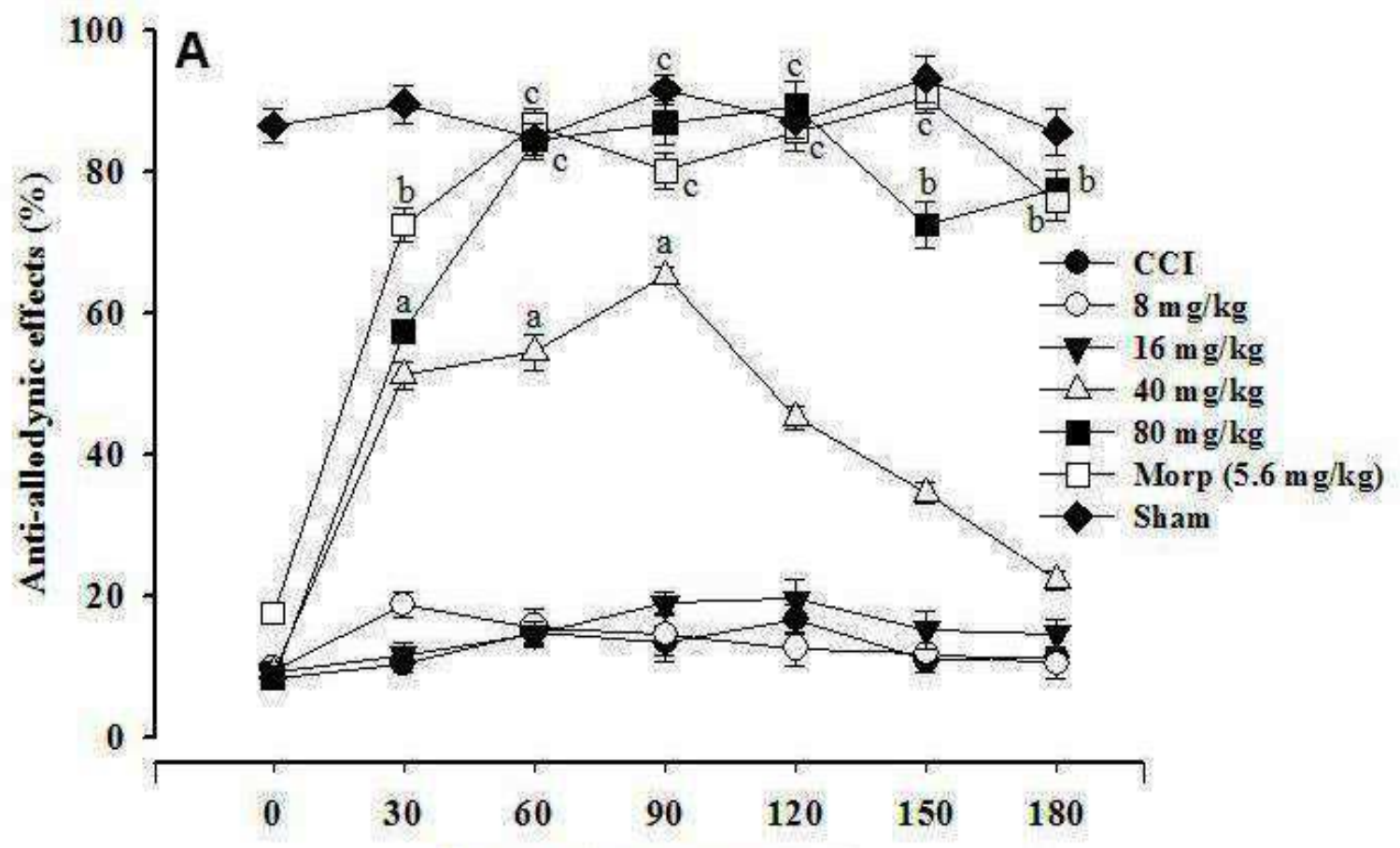

Time post-injection (min)

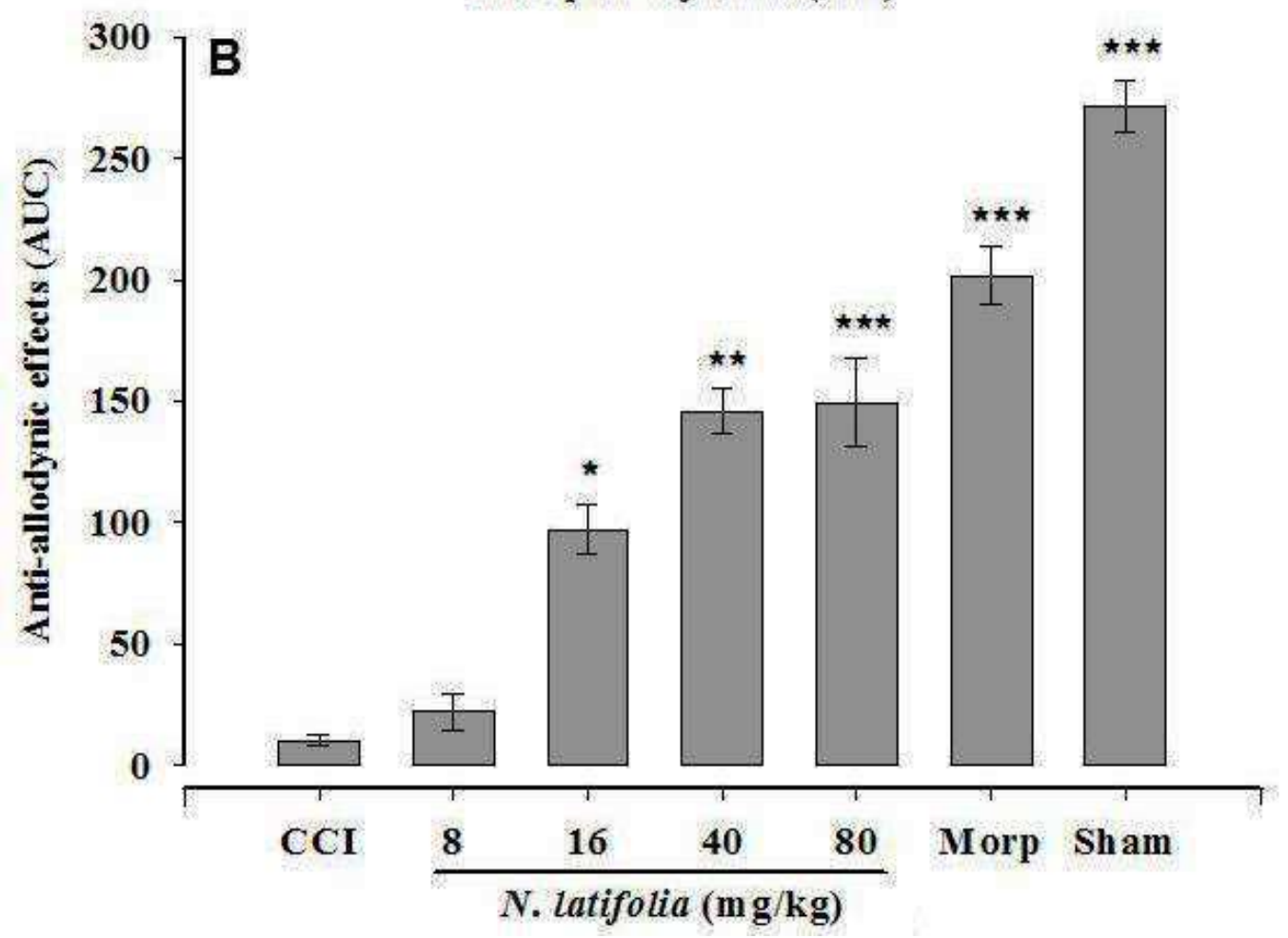

Figure 3: Germain Sotoing Taïwe et al. 


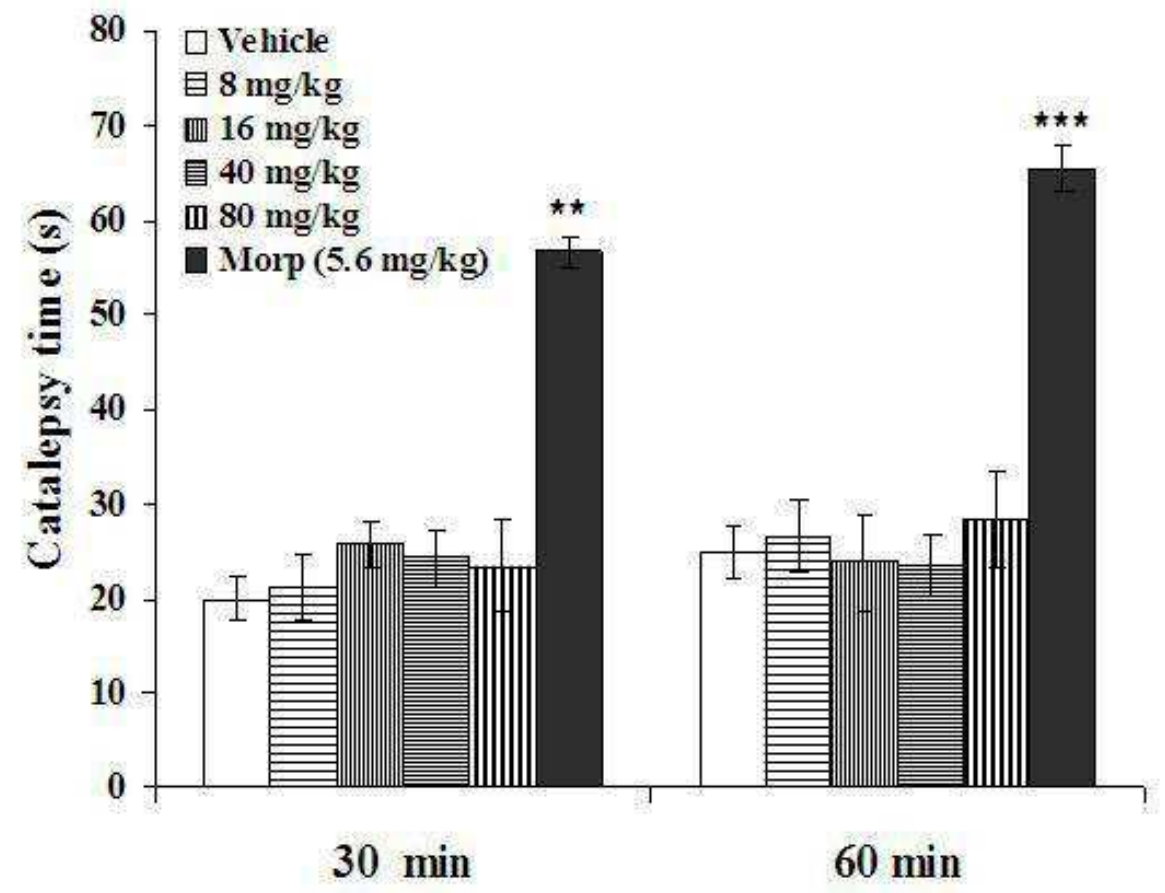

Figure 4: Germain Sotoing Taïwe et al. 


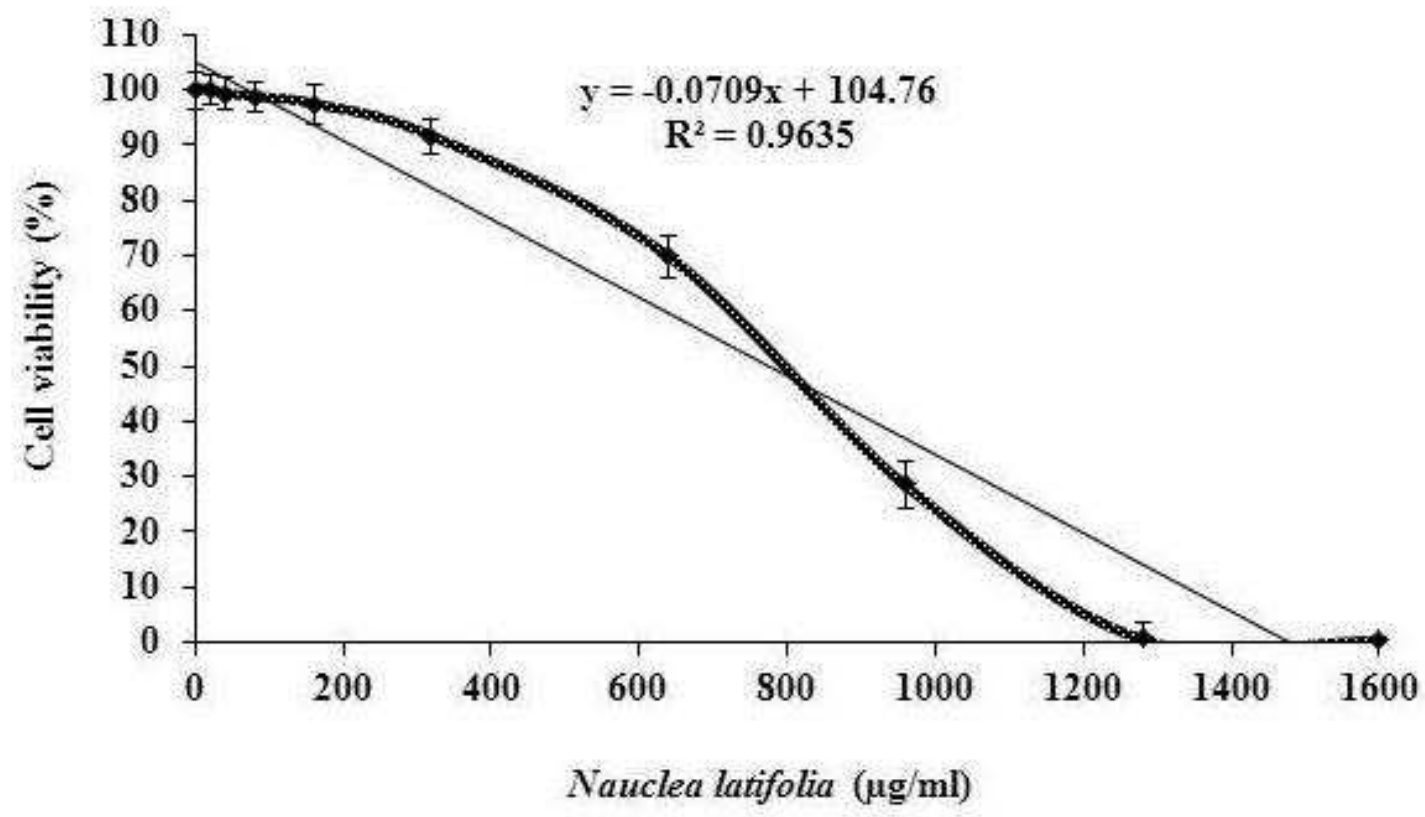

Figure 5: Germain Sotoing Taïwe et al. 